\title{
O PASSADO E O PRESENTE DA ÁFRICA E EUROPA
}

BENNETT, Herman L.. African Kings and Black Slaves: Sovereignty and Dispossession in the Early Modern Atlantic. Filadélfia: University of Pennsylvania Press, 2019. 240p.

$E_{\mathrm{m} \text { sua introdução a este importante }}$ livro, Herman Bennett começa explicando como ele próprio foi levado ao tema da soberania africana no início do mundo atlântico moderno. Como estudante de pós-graduação que fazia pesquisa no Arquivo Nacional da Torre do Tombo, em Lisboa, Bennett cruzou com uma coleção de mapas e documentos comemorativos dos quinhentos anos de contorno do Cabo da Boa Esperança (1488) por uma esquadra sob o comando de Bartolomeu Dias. Bennett observou que esses velhos documentos revelavam uma história específica da diplomacia renascentista, na medida em que os portugueses receberam como seus iguais emissários de toda a África e Ásia; algo que falava sobre uma história do poder e da soberania que, como Bennett aponta, tem sido pouco abordada pela bibliografia sobre as relações mais remotas entre a África e a Europa.

A maior parte dessa bibliografia, continua Bennett, focou nos inícios do tráfico transatlântico de escravos como a pedra fundamental dessas primeiras relações. O objetivo central de seu livro é mudar a lente discursiva para ver e imaginar o que pode resultar se assim o fazemos. Ao focar na soberania, argumenta Bennett, uma visão transformativa ocorre dos africanos enquanto governantes, sujeitos e indivíduos, e não objetos controlados pelo poder de outros. Assim, a intenção deste livro é especialmente fazer essa intervenção historiográfica, mais do que produzir novos dados empíricos, e nisto ele logrou um sucesso muito impressionante.

O interesse de Bennett é ver o que acontece quando sua lente analítica muda, quando foca o poder africano e o europeu. Há grandes áreas de interesse no livro que precisam ser destacadas. A primeira diz respeito à narrativa das relações entre africanos e europeus no primeiro século desse contato. Bennett observa uma diferença entre os primeiros relatos europeus da África e de outras partes do mundo, sugerindo que os 
portugueses não se sentiram maravilhados com sua chegada àquele continente, em contraste com a maneira com que as Américas foram descritas. Isto porque, de fato, os primeiros contatos com a África foram uma continuidade de quadros de referência preexistentes, com os africanos da Senegâmbia inicialmente retratados através de uma linguagem de conflito religioso em relação ao Islã, com o que os portugueses já estavam familiarizados. Como a região no mundo mais próxima da Europa em termos históricos e culturais, a África também se revelaria aquilo que os europeus tentavam empurrar para o mais longe de si.

De fato, a ênfase historiográfica de Bennett é mostrar as conexões simbióticas entre as histórias da África e da Europa. Nenhuma delas, ele argumenta, pode ser entendida sem a outra. A Europa não pode ser entendida senão como lugar do império, da escravidão e da raça, mas também, quanto à África, "conceitos como tradição, autenticidade, autonomia, memória cultural, protagonismo, e resistência [...] não podem ser concebidos, em sua complexidade, até que a especificidade histórica do passado europeu seja esclarecido" (pp. 12-13). Bennett, com efeito, argumenta, convincentemente, que a soberania africana e a europeia são mutuamente constituídas nesse período inicial de interconexões, de tal modo que cada uma foi constituída no espelho da outra.

A segunda grande área de interesse no livro é a análise da historiografia da escravidão e do tráfico negreiro. Bennett sustenta que, da perspectiva da história africana, o foco na escravidão é raso; e geralmente procede por meio de uma projeção regressiva, desde os séculos XVIII e XIX, e um enfoque liberal inspirado no abolicionismo triunfalista inglês, para chegar às realidades complexas dessas interações afro-ibéricas na etapa bem inicial do período pré-colonial. Assim, ao iniciar a análise nesse primeiro período e não mais tarde, Bennett almeja demonstrar o achatamento histórico que ronda muito da historiografia sobre o tópico. A objetificação e o desempoderamento dos africanos não foi uma inevitabilidade histórica quando se lê através das lentes dos debates e discursos sobre poder e soberania do período; e, mais ainda, a instituição da escravidão pode parecer como se as realidades dos séculos XVIII e XIX fossem de alguma forma a norma.

Bennett se refere a essa projeção regressiva ao insistir no primado do período inicial através do deliberado embaçamento das fronteiras disciplinares e do enfoque na categoria política de soberania. Criticando as historiografias liberais, ele aponta para o uso mais cuidadoso das fontes feito com frequência pelos antropólogos. Os historiadores falharam notavelmente em fazer valer para a África os modelos que excitam a profissão, tais como transnacionalismo e "histórias conectadas", e isto, para Bennett, reside na conexão deste campo de estudo com a era da abolição. 
É aqui que o conceito de soberania colide com as fronteiras estáticas da "história" construídas na era da abolição. Conforme Bennett, "é difícil argumentar em prol da soberania africana quando os africanos aparecem em encontros [com os europeus] como objetos" (p. 86). A tarefa seria trocar a historicização tradicional de poder e escravidão por uma mais nuançada, que não reduza tudo às relações afro-europeias do século XVIII, e assim, Bennett argumenta, compensar um achatamento da narrativa de como os africanos foram "feitos" escravos. O período inicial muda tudo. Uma leitura mais acurada das bulas papais e dos primeiros relatos de viajantes revela como os comerciantes e a monarquia portuguesa reconheciam explicitamente e dependiam da soberania africana. Os primeiros comerciantes buscaram ativamente alianças diplomáticas, reconhecendo sua valia. Assim, em lugar de fazer dos africanos objetos construídos, o livro de Bennett promove a importância de reconhecê-los enquanto sujeitos diplomáticos.

Argumento tão amplo e instrumental significa, inevitavelmente, que Bennett está em desacordo com muita da bibliografia estabelecida. O conceito de protagonismo (agency) sugerido pelo historiador estadunidense John Thornton é criticado, da mesma forma que o é a projeção do filósofo congolês Valentin-Yves Mudimbe de relações afro-europeias mais modernas em sua leitura das bulas papais quatrocentistas. Mas para além da crítica de africanistas, mais abrangente e significativo é que African Kings and Black Slaves questiona toda a genealogia do poder e da historiografia ocidentais. É um livro que merece leitura e releitura cuidadosa e atenta, tantos os argumentos e críticas que são feitos e tão multiplamente conectados que são. Como Bennett observa, os teóricos ocidentais do poder conceberam a soberania sem qualquer referência a sua relação fundacional com a escravidão. O absolutismo e a colonialidade, como têm sido concebidos, são fundamentalmente construídos sem qualquer referência ao sujeito africano.

Uma vez que essa subjetividade, soberania e autonomia sejam reconhecidas, esses conceitos e histórias parecerão radicalmente diferentes - e merecem e precisam ser debatidas e concebidas de forma diferente. Nesta era de hegemonia de uma superestrutura ideológica corporativista e racista, essa é uma conclusão que pode ter implicações abrangentes para estudiosos que hoje labutam em todas as disciplinas.

Tradução de João José Reis

Toby Green

King's College, London toby.green@kcl.ac.uk 